\title{
Comparative evaluation of conventional RT-PCR and real-time RT-PCR (RRT-PCR) for detection of avian metapneumovirus subtype $A$
}

\author{
Comparação entre as técnicas de RT-PCR convencional e RT-PCR em tempo real para a detecção do \\ metapneumovírus aviários subtipo A
}

\author{
Helena Lage Ferreira' ${ }^{I}$ Fernando Rosado Spilki ${ }^{I I}$ Márcia Mercês Aparecida Bianchi dos Santos ${ }^{\text {III }}$ \\ Renata Servan de Almeida ${ }^{\mathrm{IV}}$ Clarice Weis Arns ${ }^{\mathrm{II}}{ }^{*}$
}

\begin{abstract}
Avian metapneumovirus (AMPV) belongs to Metapneumovirus genus of Paramyxoviridae family. Virus isolation, serology, and detection of genomic RNA are used as diagnostic methods for AMPV. The aim of the present study was to compare the detection of six subgroup A AMPV isolates (AMPV/A) viral RNA by using different conventional and real time RT-PCR methods. Two new RT-PCR tests and two real time RT-PCR tests, both detecting fusion (F) gene and nucleocapsid $(N)$ gene were compared with an established test for the attachment $(G)$ gene. All the RT-PCR tested assays were able to detect the AMPV/A. The lower detection limits were observed using the $N$-, F- based RRT-PCR and F-based conventional RT-PCR $\left(10^{0.3}\right.$ to $10^{1}$ TCID $\left.\mathrm{mL}^{-1}\right)$. The present study suggests that the conventional F-based RT-PCR presented similar detection limit when compared to $N$ - and F-based RRT-PCR and they can be successfully used for AMPV/A detection.
\end{abstract}

Key words: avian metapneumovirus, $G, F, N$ genes, real time $R T-P C R, R T-P C R$.

\section{RESUMO}

O metapneumovírus aviário (AMPV) pertence ao gênero Metapneumovirus, família Paramyxoviridae. Isolamento viral, sorologia e detecção do RNA genômico são atualmente as técnicas utilizadas para o diagnóstico desse agente. O objetivo do presente estudo foi comparar a detecção de RNA viral de seis isolados de AMPV, subtipo A (AMPV/A), utilizando diferentes métodos de RT-PCR convencional e real time RT-PCR (RRT-PCR). Duas novas técnicas de RT-PCR convencional e duas técnicas de RRT-PCR, ambas para a deteç̧ão dos genes da nucleoproteína $(N)$ e da proteína de fusão $(F)$, foram comparadas com um RT-PCR previamente estabelecido para a detecção do AMPV (gene da glicoproteína -G). Todos esses métodos foram capazes de detectar os isolados AMPV/A. As técnicas RRT-PCR (genes F e N) mostraram os menores limites de detecção $\left(10^{0.3}\right.$ to $\left.10^{1} \mathrm{TCID}_{50} \mathrm{~mL}^{-1}\right)$. Os resultados sugerem que as técnicas $R T-P C R$ convencional (gene F) e as técnicas de RRT-PCR (gene $F$ e N) desenvolvidas no presente estudo podem ser utilizadas com sucesso para a detecção do AMPV/A. Além disso, o RRT-PCR gera resultados rápidos e sensíveis, o que o torna uma ferramenta alternativa para o isolamento viral.

Palavras-chave: metapneumovírus aviário, genes $G, F, N$, real time RT-PCR, RT-PCR.

\section{INTRODUCTION}

The avian metapneumovirus (AMPV), previously called avian pneumovirus (APV) or turkey rhinotracheitis virus (TRTV), is a member of the Paramyxoviridae family, Pneumovirinae subfamily, within the new genus Metapneumovirus (FAUQUET et al., 2005). It contains a non-segmented, negativesense RNA genome of approximately 13,000nt length. The AMPV genome is composed by eight viral genes arranged in the following order: nucleocapsidphosphoprotein-matrix-fusion-second matrix-small

\footnotetext{
IAvian Virology and Immunology, Veterinary and Agrochemical Research Institute, Groeselenberg 99, B-1180 Brussels, Belgium. "Instituto de Ciências da Saúde, Centro Universitário Feevale, Novo Hamburgo, RS, Brasil.

IIIDepartamento de Microbiologia e Imunologia, Instituto de Biologia, Laboratório de Virologia Animal, Universidade de Campinas (UNICAMP), 06109, Campinas, SP, Brasil. E-mail: arns@unicamp.br. *Autor para correspondência.

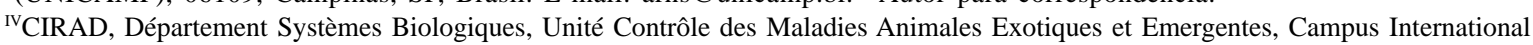
de Baillarguet, 34398, Montpellier, France.
} 
hydrophobic-glycoprotein-large polymerase ('3-NP-M-F-M2-SH-G-L-5')(GOUGH, 2003).

AMPV causes acute rhinotracheitis characterized by coughing, nasal discharge and conjunctivitis in turkeys. In chickens, AMPV plays a role, in association with bacteria, on the development of swollen head syndrome. AMPV infection is also associated to egg drop in turkeys and ducks (GOUGH, 2003). The virus was first described causing clinical evident disease in South Africa. Nonetheless, major outbreaks of the disease were later reported in Europe, United States (US), United Kingdom, Middle East, Asia, and in other parts of the world (COOK \& CAVANAGH, 2002). AMPV is also present in Brazilian flocks since at least 1992 (ARNS \& HAFEZ, 1992).

Diagnosis of AMPV infection can be achieved by virus isolation in chicken or turkey tracheal tissue cultures (TOC). Alternatively, it can be obtained from cell cultures (D'ARCE et al., 2005; GIRAUD et al., 1986). Other methods allow the identification and characterization of AMPV, such as immunofluorescence staining or virus neutralization of the isolate with polyclonal or monoclonal antibodies (OTSUKI et al., 1996). Among serological methods, the ELISA(GIRAUD et al., 1986) is the most commonly used. However, serological results are delayed for at least 15 days needed for seroconversion. Molecular methods, such as reverse transcriptase- polymerase chain reaction (RTPCR), allow the development of rapid, sensitive and specific detection of AMPV (BÄYON-AUBOYER et al., 1999; D’ARCE et al., 2005; DANI et al., 1999; GUIONIE et al., 2007; JUHASZ \& EASTON, 1994). Different conventional RT-PCR were already developed by using primers defined either for the detection of all subgroups (BÄYON-AUBOYER et al., 1999; CECCHINATO et al., 2004), or for the specific identification of each of subgroups A-D (BÄYONAUBOYER et al., 1999). In a recent study, sets of primers targeting attachment $(\mathrm{G})$ gene and small hydrophobic (SH) gene were designed to identify the four AMPV subgroups by real time RT-PCR (RRT-PCR), which also provides the quantification of mRNAs (GUIONIE et al., 2007). Several RRT-PCR assays were also developed for detection of human metapneumovirus (hMPV) targeting fusion (F), nucleoprotein (N), phosphoprotein $(\mathrm{P})$, and polymerase $(\mathrm{L})$ genes (MAERTZDORF et al., 2004; PABBARAJU et al., 2007).

Different target genes can apparently alter the sensibility and specificity of virus detection by conventional (CECCHINATO et al., 2004) and RRTPCR assays. Primers and probes targeting NS1, NP-1, and VP1 genes of Human bocavirus (HBoV) showed similar sensitivity and specificity in RRT-PCR assays
(CHOI et al., 2008). On the other hand, nucleocapsid target genes were found to be consistently more sensitive than the polymerase targets of SARS coronavirus (SARS-CoV) in RRT-PCR tests (KEIGHTLEY et al., 2005). The aim of the present study was to compare the sensitivities and specificities of two newly defined conventional RT-PCR assays, two RRT-PCR tests detecting the $\mathrm{F}$ and $\mathrm{N}$ genes (FERREIRA et al., 2007), and an established test for the attachment (G) gene (BÄYON-AUBOYER et al., 1999) for detection of AMPV/A isolates.

\section{MATERIALS AND METHODS}

Virus strains: in this study, six Brazilian AMPV viruses were propagated in chicken embryorelated cell (CER) cultures. These viruses were isolated from trachea and nasal exudates in CER cells and they were named: chicken/A/BR/119/95, chicken/A/BR/121/ 95, SHSBR/662/03, SHSBR/668/03, SHSBR/669/03 and TRTBR/169, previously classified as AMPV/A(D'ARCE et al., 2005; DANI et al., 1999).

RNA extraction and reverse transcription (RT): Total RNA was extracted from $200 \mu \mathrm{L}$ of infected cell cultures using High Pure Viral RNA kit (Roche, Mannheim, Germany), according to manufacturer's recommendations. A $5 \mu \mathrm{L}$ RNA sample was used for the generation of cDNA using 60ng of a hexamer primer (Invitrogen, Carlsbad, CA, USA) and Superscript III reverse transcriptase enzyme (Invitrogen, Carlsbad, CA, USA) with final volume of $20 \mu \mathrm{L}$ according to manufacturer's recommendations.

Conventional RT-PCR: two different pairs of AMPV-specific primers targeting the N, F genes were designed based on the conserved regions of the nucleotide sequences available for the $\mathrm{F}$ and $\mathrm{N}$ genes of AMPV/A to perform the conventional RT-PCR (Table 1). Also, AMPV-specific primers targeting the $G$ gene previous described by BÄYON-AUBOYER et al. (1999) were used to compare the AMPV detection (Table 1). PCR reaction of $\mathrm{N}$ and $\mathrm{F}$ genes was performed using the Taq DNA Polymerase Recombinant (Invitrogen, Carlsbad, USA), with final concentrations of $1 \mathrm{X}$ PCR buffer, $0.3 \mathrm{mM}$ of dNTP mixture, $0.125 \mathrm{mM}$ of $\mathrm{MgCl}_{2}$, $0.2 \mu \mathrm{M}$ of each primer in a total reaction volume of $25 \mu \mathrm{L}$ containing $1 \mu \mathrm{L}$ of cDNA. Individual PCR amplification cycle of $\mathrm{N}$ or $\mathrm{F}$ genes was performed with an initial denaturation step at $94^{\circ} \mathrm{C}$ for $3 \mathrm{~min}$, followed by 35 cycles $\left(94^{\circ} \mathrm{C}\right.$ for $30 \mathrm{~s} ; 53^{\circ} \mathrm{C}$ for $30 \mathrm{~s} ; 72^{\circ} \mathrm{C}$ for $60 \mathrm{~s}$ ), and finally with an elongation step at $72^{\circ} \mathrm{C}$ for $7 \mathrm{~min}$. PCR reaction and amplification cycle of the $\mathrm{G}$ gene were performed as previously described (BÄYON-AUBOYER et al., 1999). PCR products (N gene-698bp; F gene- 698bp; $G$

Ciência Rural, v.39, n.5, ago, 2009. 
Table 1 - Primers and probes for each amplified AMPV/A gene by RT-PCR and RRT-PCR.

\begin{tabular}{|c|c|c|c|c|c|}
\hline Molecular test & Gene & Primers or Taqman ${ }^{\circledR}$ probes & Positions* & Sequence (5'- 3') & Ref. \\
\hline \multirow{2}{*}{ RT-PCR } & \multirow{2}{*}{$\mathrm{N}$} & $\mathrm{Nf}$ & $215-235$ & GCAAAACACACCGACTATGAG & \multirow{2}{*}{ this study } \\
\hline & & $\mathrm{Nr}$ & 892-912 & TAGACCTCAGATACTTGCCTC & \\
\hline \multirow{3}{*}{$\begin{array}{l}\text { Real time RT- } \\
\text { PCR }\end{array}$} & \multirow{3}{*}{$\mathrm{N}$} & AMPVN+494 & $494-514$ & CAAAAGCCGTCTGCCTTGGAT & \multirow{3}{*}{$\begin{array}{c}\text { (FERREIRA } \\
\text { et al. 2007) }\end{array}$} \\
\hline & & AMPVN-567 & $547-567$ & GAGGCCAACTTGGTGAAAATG & \\
\hline & & AMPVN+516FAMTAMRA & $516-545$ & CTCCCGTTATTCTATTATGCATTGGTGCCC & \\
\hline \multirow{2}{*}{ RT-PCR } & \multirow{2}{*}{$\mathrm{F}$} & $\mathrm{Ff}$ & 3178-3198 & AGGGAGCTCAAAACAGTGTCA & \multirow{2}{*}{ this study } \\
\hline & & $\mathrm{Fr}$ & $3855-3875$ & CAGTACCACCCTTGATCTTCT & \\
\hline \multirow{3}{*}{$\begin{array}{l}\text { Real time RT- } \\
\text { PCR }\end{array}$} & \multirow{3}{*}{$\mathrm{F}$} & AMPVF+3643 & $3643-3663$ & ATGCCAACTTCATCAGGACAGA & \multirow{3}{*}{$\begin{array}{c}\text { (FERREIRA } \\
\text { et al. 2007) }\end{array}$} \\
\hline & & AMPVF-3721 & $3700-3721$ & TСААТАТАССАААССССТТССТТСТ & \\
\hline & & $\begin{array}{c}\text { AMPVF+3667FAMTAMR } \\
\text { A }\end{array}$ & $3367-3394$ & AGTTTGATGTTGAACAATCGTGCCATGGT & \\
\hline \multirow[b]{2}{*}{ RT-PCR } & \multirow[b]{2}{*}{ G } & Ga1 & $5944-5964$ & CCGGGACAAGTATCYMKATGG & \multirow{2}{*}{$\begin{array}{c}\text { (BÄYON- } \\
\text { AUBOYER } \\
\text { et al. 1999) }\end{array}$} \\
\hline & & Gy & $6390-6412$ & TCTCGCTGACAAATTGGTCCTGA & \\
\hline
\end{tabular}

*Nucleotide numbering based on avian metapneumovirus genome (GenBank accession no. AY640317).

gene- 448bp) were observed in $1 \%$ agarose gel electrophoresis, stained with ethidium bromide. Ultrapure water was used as the negative template control (NTC).

Real time RT-PCR(RRT-PCR): Real-time PCR amplification (RRT-PCR) of $\mathrm{N}$ and $\mathrm{F}$ genes were performed as previously described (FERREIRA et al., 2007). Primers and Taqman ${ }^{\circledR}$ probes targeting the $\mathrm{N}$ and F mRNAs were used (Table 1). Briefly, the Quantitec Probe PCR kit (Qiagen, Hilden, Germany) was used with final concentrations of $900 \mathrm{nM}$ of each primer, and $300 \mathrm{nM}$ of the Taqman ${ }^{\circledR}$ probe in a total individual reaction volume of $25 \mu \mathrm{L}$ containing $1 \mu \mathrm{L}$ of $\mathrm{cDNA}(0.2$ to 20ng). An external standard curve was created using spectrophotometrically determined copy number standards of purified PCR product for each gene. After an initial reverse transcription step and an initial denaturation step at $95^{\circ} \mathrm{C}$ for $15 \mathrm{~min}, 50$ cycles $\left(95^{\circ} \mathrm{C}\right.$ $15 \mathrm{sec}-60^{\circ} \mathrm{C} 1 \mathrm{~min}$ ) were performed with fluorescence detection at the end of the annealing-extension step. Amplification and fluorescence detection were carried out in an Applied Biosystems 7500 real time PCR cycler (Applied Biosystems, Foster City, USA). For absolute quantification, a PCR product containing the target sequence was used as DNA standard. The experiments were repeated three times on different days from the same cDNA stocks. Threshold cycle values (Ct) were used, as Ct indicates the PCR cycle number at which the amount of amplified target reaches a fixed threshold. In order to convert threshold cycles in copy numbers, an external standard curve was created with known copy numbers of $\mathrm{F}$ gene and $\mathrm{N}$ gene of AMPV. Copy number was calculated using the following formula:

Y molecules $\mu \mathrm{L}^{-1}=\left(\mathrm{Xg} \mu \mathrm{L}^{-1} \mathrm{DNA} /\right.$ [Length of PCR product in base pairs x 660]) x $6.022 \times 10^{23}$ ).

Detection Limit: In addition, 10 -fold serial dilutions in DMEM of isolates chicken/A/BR/121/95 and SHSBR/669/03 were also extracted and used to evaluate the detection limit of each test. The titers from each isolate were performed in CER cells and calculated by the Reed-Muench method (REED \& MUENCH, 1938) and expressed as median 50\% tissue culture infectious dose (TCID $_{50}$ ) per mL of viral suspension.

Specificity: specificity tests were performed from stocks of other RNA viruses, including, infectious bronchitis virus (IBV) and respiratory syncytial virus (hRSV). One strain (STG SHS-1439, AMPV/B) from Germany was included in the analysis. Non-infected supernatants from CER cells were used as negative control.

\section{RESULTS}

Conventional RT-PCR: all the six isolates were detected using conventional G, F-, and N-based, RT-PCR (Figure 1A). The RT-PCR products had the appropriated size on ethidium bromide stained agarose gels. All negative and blank controls were negative using conventional RT-PCR (data not shown).

RRT-PCR: the N- and F- based RRT-PCR assays were also able to detect all isolates (Table 2). A standard curve for $\mathrm{N}$ gene AMPV quantification was 


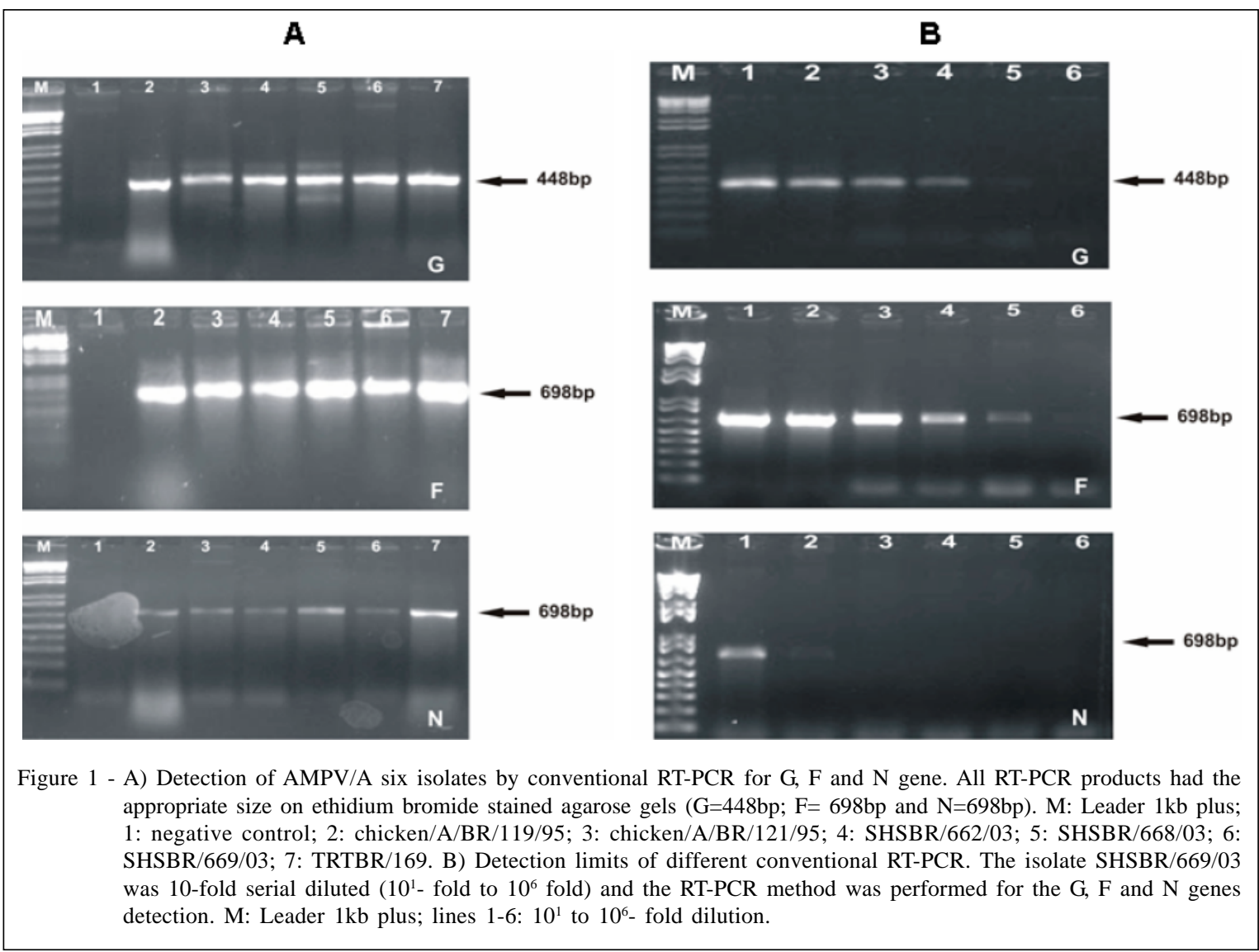

established using a PCR product containing a target sequence serially diluted from $8 \times 10^{0}$ to $8 \times 10^{-7}$. The standard curve showed an efficacy of $98.71 \%$, a slope of -3.353247 , a regression coefficient of 0.993317 , and an intercept of 45.66. For the N- based RRT-PCR, Ct values ranging from $18.39 \pm 0.434$ to $23.70 \pm 0.199$. The standard curve of $\mathrm{F}$ gene AMPV quantification was generated using $\mathrm{F}$ target sequence serially diluted from $10^{0}$ to $10^{-8}$. RRT-PCR efficiency was $99.95 \%$, slope was -3.3229, a regression coefficient was 0.998116 , with an intercept of 49.621. For the F-based RRT-PCR, the tested isolates showed $\mathrm{Ct}$ values ranging from $19.69 \pm 0.032$ to $25.55 \pm 0.180$.

Detection limit: in order to evaluate the detection limit, eight serial 10-fold dilutions in DMEM were prepared from two different isolates (chicken/A/ BR/121/95 and SHSBR/669/03), and RNA was extracted (Table 3). The chicken/A/BR/121/95 titer ranges $10^{5.3}$ $10^{0.3} \mathrm{TCID}_{50} \mathrm{~mL}^{-1}$, equivalent to $10^{4.3}-10^{-1.3} \mathrm{TCID}_{50}$ per reaction mix by using $\mathrm{N}$ - and F- based RRT-PCR, and Fbased conventional RT-PCR. The SHSBR/669/03 titer ranges $10^{6.0}-10^{1.0} \mathrm{TCID}_{50} \mathrm{~mL}^{-1}$, equivalent to $10^{5.0}-10^{0.0}$

Table 2 - Ct values and standard deviation of real time RT-PCR (F and N genes) in detecting the AMPV/A isolates.

\begin{tabular}{lcccccc}
\hline Isolate & - & Copy numbers & Std Deviation & Ct value & Copy numbers & Std Deviation \\
\hline chicken/A/BR/119/95 & Ct value & Cop--on & & & \\
chicken/A/BR/121/95 & 19.69 & $6.89 \times 10 \mathrm{e} 8$ & \pm 0.039 & 23.49 & $3.03 \times 10 \mathrm{e} 6$ & \pm 0.217 \\
SHSBR/662/03 & 23.12 & $3.63 \times 10 \mathrm{e} 7$ & \pm 0.083 & 22.49 & $4.67 \times 10 \mathrm{e} 6$ & \pm 0.434 \\
SHSBR/668/03 & 20.85 & $1.07 \times 10 \mathrm{e} 8$ & \pm 0.225 & 21.89 & $5.49 \times 10 \mathrm{e} 6$ & \pm 0.015 \\
SHSBR/669/03 & 25.55 & $6.38 \times 106$ & \pm 0.180 & 23.70 & $3.23 \times 10 \mathrm{e} 6$ & \pm 0.199 \\
TRTBR/169 & 20.05 & $3.46 \times 10 \mathrm{e} 8$ & \pm 0.200 & 19.97 & $1.20 \times 10 \mathrm{e} 7$ & \pm 0.298 \\
Negative control & Undetermined & Undetermined & & Undetermined & Undetermined & \\
\hline
\end{tabular}

Ciência Rural, v.39, n.5, ago, 2009. 
Table 3 - Comparison of conventional RT-PCR (G, F, and N gene) and real time real time RT-PCR (F and N gene) assays and their detection limits in detecting serially diluted AMPV viral suspensions. Idem 1.

\begin{tabular}{|c|c|c|c|c|c|c|}
\hline \multirow[t]{2}{*}{ Viruses } & \multirow[t]{2}{*}{$\mathrm{TCID}_{50} \mathrm{~mL}^{-1}$} & \multirow{2}{*}{$\begin{array}{l}\text { G-based RT-PCR } \\
\text { Length (448bp) }\end{array}$} & \multirow{2}{*}{$\begin{array}{l}\text { F-based RT-PCR } \\
\text { Length (698bp) }\end{array}$} & \multirow{2}{*}{$\begin{array}{l}\text { F-based } \\
\text { RRT-PCR } \\
\mathrm{Ct}^{2} \text { value }\end{array}$} & \multirow{2}{*}{$\begin{array}{l}\text { N-based RT-PCR } \\
\text { Length (698bp) }\end{array}$} & \multirow{2}{*}{$\begin{array}{c}\text { N-based RRT- } \\
\text { PCR } \\
\text { Ct value }\end{array}$} \\
\hline & & & & & & \\
\hline \multirow[t]{8}{*}{ chicken/A/BR/121/95 } & $10^{5.3}$ & Positive & Positive & $21.57 \pm 0.051$ & Positive & $21.48 \pm 0.123$ \\
\hline & $10^{4.3}$ & Positive & Positive & $25.15 \pm 0.082$ & Positive & $25.02 \pm 0.075$ \\
\hline & $10^{3.3}$ & Positive & Positive & $27.44 \pm 0.141$ & Negative & $27.74 \pm 0.105$ \\
\hline & $10^{2.3}$ & Positive & Positive & $31.59 \pm 0.165$ & Negative & $32.04 \pm 0.273$ \\
\hline & $10^{1.3}$ & Positive & Positive & $34.21 \pm 0.191$ & Negative & $35.79 \pm 0.189$ \\
\hline & $10^{0.3}$ & Negative & Positive & $38.12 \pm 0.397$ & Negative & $38.39 \pm 0.315$ \\
\hline & $10^{-1.3}$ & Negative & Negative & Undetermined & Negative & Undetermined \\
\hline & $10^{-2.3}$ & Negative & Negative & Undetermined & Negative & Undetermined \\
\hline \multirow[t]{8}{*}{ SHSBR/669/03 } & $10^{6}$ & Positive & Positive & $19.47 \pm 0.086$ & Positive & $19.39 \pm 0.126$ \\
\hline & $10^{5}$ & Positive & Positive & $23.05 \pm 0.168$ & Positive & $22.93 \pm 0.170$ \\
\hline & $10^{4}$ & Positive & Positive & $26.77 \pm 0.154$ & Negative & $27.18 \pm 0.153$ \\
\hline & $10^{3}$ & Positive & Positive & $29.69 \pm 0.263$ & Negative & $30.26 \pm 0.015$ \\
\hline & $10^{2}$ & Positive & Positive & $32.65 \pm 0.082$ & Negative & $33.17 \pm 0.436$ \\
\hline & $10^{1}$ & Negative & Positive & $37.65 \pm 0.220$ & Negative & $38.19 \pm 0.616$ \\
\hline & $10^{0}$ & Negative & Negative & Undetermined & Negative & Undetermined \\
\hline & $10^{-1}$ & Negative & Negative & Undetermined & Negative & Undetermined \\
\hline
\end{tabular}

TCID $_{50} \mathrm{~mL}^{-1}: 50 \%$ tissue culture infectious dose per $\mathrm{mL}$; Ct value : Threshold cycle values.

TCID $_{50}$ per reaction mix by using $\mathrm{N}$ - and F-based RRTPCR, and F-based conventional RT-PCR. The N-based conventional RT-PCR presented detection limit of $10^{4.3}$ and $10^{5.0} \mathrm{TCID}_{50} \mathrm{~mL}^{-1}$ from chicken/A/BR/121/95 and SHSBR/669/03 isolates, respectively (Figure $1 \mathrm{~B}$ ). The G-based conventional RT-PCR showed detection limit of two isolates ranging to $10^{1.3}$ to $10^{2.0} \mathrm{TCID}_{50} \mathrm{~mL}^{-1}$. The best detection limits were obtained by using N-, Fbased RRT-PCR and F-based conventional RT-PCR assays, which could detected detection limits ranging from $10^{0.3}$ to $10^{1} \mathrm{TCID}_{50} \mathrm{~mL}^{-1}$ of both isolates (Table 3 ). Our group was able to recover virus titers up to $10^{4.55}$ TCID $_{50} \mathrm{~mL}^{-1}$ at $5 \mathrm{dpi}$ from oral swabs, after experimental infection with $10^{5} \mathrm{TCID}_{50} \mathrm{~mL}^{-1} \mathrm{AMPV} / \mathrm{A}$ and AMPV/B in chickens (unpublished data). This suggests that evaluated RT-PCR and RRT-PCR assays could be used for AMPV detection and quantification in experimental studies.

Specificity: the specificity of RT-PCR detection methods was evaluated using different RNA viruses. The developed methods were found to be specific for AMPV/A, as no amplifications was detected for other RNA viruses. No specific band was visualized by $\mathrm{N}$ - and $\mathrm{F}$ - based conventional RT-PCR tests and $\mathrm{Ct}$ values were undetermined by $\mathrm{N}$ - and F-based RRTPCR assays). The conventional RT-PCR for the $\mathrm{G}$ gene could detect AMPV/A and AMPV/B.

\section{DISCUSSION}

BÄYON-AUBOYER et al. (1999) described the ability of the G- based RT-PCR assay to detect AMPV/A and AMPV/B in field samples. Our results are in agreement with these authors because the Gbased RT-PCR was able to detect the AMPV subtypes $\mathrm{A}$ and $\mathrm{B}$. The conventional F-based RT-PCR and the RRT-PCR tested assays could specifically detect AMPV/A. BÄYON-AUBOYER et al. (1999) also reported that the G-based RT-PCR method was sensitive enough to detect AMPV in swabs without requiring previous virus propagation.

Interestingly, it is important to note that the detection limit of F-based conventional RT-PCR sustains comparison with RRT-PCR tested assays detection limits (detection of $10^{0.3}$.to $10^{1} \mathrm{TCID}_{50} \mathrm{~mL}^{-1}$ ). This fact could be explained by the presence of a pyrimidine residue at their 3' end in primers AMPVspecific targeting the $\mathrm{F}$ gene. This parameter was suggested to increase the sensitivity in some PCR primers designed to detect an AMPV/A cloned F gene (CECCHINATO et al., 2004). The sensitivity of the Nand F-based RRT-PCR seemed to be lower than the recently reported G-based RRT-PCR for AMPV/A detection (10-1.5 TCID $_{50} \mathrm{~mL}^{-1}$; GUIONIE et al., 2007). Nonetheless, a previous study also described that the 
N-based RT-PCR was more sensitive than other tests targeting different genes (MAERTZDORF et al., 2004). We could expect this due to the polarity exhibited during the transcription process. The genes closer to the promoter ( 3 'end of the negative-strand genome) are most abundantly transcribed in non-segmented negative-strand RNA viruses (BARIK, 1992). The N gene is the promoter closest gene, thus, the transcription process produces more N mRNA than G genes. Surprisingly, conventional N-based RT-PCR had the highest detection limit when compared with conventional F- and G- based RT-PCR assays for AMPV detection. The absence of a pyrimidine residue at their 3'in the primers AMPV-specific targeting the $\mathrm{N}$ gene can play on the sensitivity of conventional RT-PCR assays. On the other hand, the primers of tested RRTPCR assays do not contain this parameter and no difference in the sensitivity was observed when compared N- and F- based RRT-PCR. The impact of pyrimidine residue at their 3' in the primers for RRTPCR assays should be further investigated.

In addition, some positive signals can be detected due to non-specific amplification and/or probe disruption at the end of the amplification process in absence of target cDNA (LOISY et al., 2005). We considered thus that $\mathrm{C}$ values higher than 39 may indicate either a problematic sample, or RNA purification, or RRT-PCR reaction.

\section{CONCLUSION}

The present study shows that the conventional F-based RT-PCR presented similar sensitivity when compared to $\mathrm{N}$ - and F-based RRTPCR and they can be successfully used for AMPV/A detection. Nonetheless, they should be used in association with conventional G-based RT-PCR for AMPV diagnosis, because it also detects $\mathrm{N}$ and $\mathrm{D}$ AMPV subgroups. The conventional F-based RT-PCR could also provide further nucleotide sequencing, which allows phylogenetic studies on the detected isolates. On the other hand, RRT-PCR assays can offer targeted mRNA detection, generating quantitative data. Although the RRT-PCR assays remains to be evaluated with field samples and it would be useful to virus shedding quantification in vaccine studies.

\section{ACKNOWLEDGEMENTS}

We are thankful to Geneci F. Davi and Paula S. Porto for their excellent technical assistance, Steven Van Borm and Tiago C. Pereira for providing sequence information for primer and probes synthesis, Prof Hafez M Hafez for providing the German strain (STG SHS1439). This work was supported by FAPESP grant number 03/14012-9.

\section{REFERENCES}

ARNS, C.W.; HAFEZ, M.H. Swollen head syndrome in poultry flocks in Brazil. In: WESTERN POULTRY DISEASE CONFERENCE, 41., 1992, Sacramento, USA. Proceedings... Davis, CA: Conference \& Event Services, University of California, 1992. p.81-84.

BARIK, S. Transcription of human respiratory syncytial virus genome RNA in vitro: requirement of cellular factor(s). Journal of Virology, v.66, p.6813-6818, 1992.

BÄYON-AUBOYER, M.H. et al. Comparison of F-, G- and Nbased RT-PCR protocols with conventional virological procedures for the detection and typing of turkey rhinotracheitis virus. Archives of Virology, v.144, n.6, p.1091-1109, 1999. Disponível em: <http://www.springerlink.com/content/ vxcm8vulvfx3vmeh>. Doi: 10.1007/s007050050572.

CECCHINATO, M. et al. Design, validation, and absolute sensitivity of a novel test for the molecular detection of avian pneumovirus. Journal of Veterinary Diagnostic Investigation, v.16, n.6, p.582-585, 2004

CHOI, J.H. et al. Development of real-time PCR assays for detection and quantification of human bocavirus. Journal of Clinical Microbiology, v.42, n.3, p.249-253, 2008. Disponível em: <http://www.journalofclinicalvirology.com/ article/S1386-6532(08)00070-X>. Doi: 10.1016/ j.jcv.2008.02.010.

COOK, J.K.; CAVANAGH, D. Detection and differentiation of avian pneumoviruses (metapneumoviruses). Avian Pathology, v.31, n.2, p.117-132, 2002.

D’ARCE, R.C. et al. Subtyping of new Brazilian avian metapneumovirus isolates from chickens and turkeys by reverse transcriptase-nested-polymerase chain reaction. Avian Pathology, v.34, n.2, p.133-136, 2005.

DANI, M.A. et al. Molecular characterization of Brazilian avian pneumovirus isolates: comparison between immunochemiluminescent Southern blot and nested PCR. Journal of Virological Methods, v.79, n.2, p.237-241, 1999. Disponível em: <http://www.sciencedirect.com/ science?_ob=MImg\&_imagekey=B6T96-3WJDTS6-D$7 \&$ \& c di $=5106 \&$ \&_us e r $=687304 \&$ \&_orig = s e a r ch \&_c over Date $=05 \% 2$ F $31 \% 2$ F $1999 \&$ \& k = $999209997 \& \mathrm{vi}$ e w $=$ c \& w c h p =d G L b V l W zSkzS\&md5=6b42016b9f823422152fecdd9a0d7060\&ie=>. Doi: 10.1016/S0166-0934(99)00020-8.

FAUQUET, C.M. et al. Virus taxonomy: VIIIth Report of the International Committee on Taxonomy of Viruses. Amsterdam: Elsevier Academic, 2005. 1162p.

FERREIRA, H.L. et al. Inhibition of avian metapneumovirus (AMPV) replication by RNA interference targeting nucleoprotein gene (N) in cultured cells. Antiviral Research, v.74, n.1, p.7781, 2007. Disponível em : <http://www.sciencedirect.com/ science?_ob=MImg\&_imagekey=B6T2H-4MR1GV1-1-

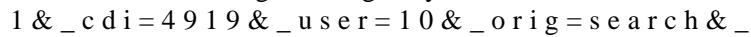
c o v e r D a t e $=04 \% 2$ F $30 \% 2 \% 2007$ \& $\mathrm{s} \mathrm{k}=999259998$ \& vi e w $=\mathrm{c} \& \mathrm{w} \mathrm{ch}$ h $=\mathrm{d}$ G L z V t b zSkWb\&md5=a1d63aa0ca8ae7b4fa06307793e8edc5\&ie=>. Doi: 10.1016/j.antiviral.2006.12.002. 
GIRAUD, P. et al. Turkey rhinotracheitis in France: preliminary investigations on a ciliostatic virus. Veterinary Record, v.119, n.24, p.606-607, 1986.

GOUGH, R.E. Avian pneumoviruses. In: SAIF, M. et al. Diseases of poultry. Ames: Iowa State, 2003. p.92-99.

GUIONIE, O. et al. Laboratory evaluation of a quantitative real-time reverse transcription PCR assay for the detection and identification of the four subgroups of avian metapneumovirus. Journal of Virological Methods, v.139, n.2, p.150-158, 2007. Disponível em : <http:// www.sciencedirect.com/science?_ob=MImg\&_imagekey=B6T964MFJJ12-1-3\&_cdi=5106\&_user=10\&_orig=search\&_coverDa

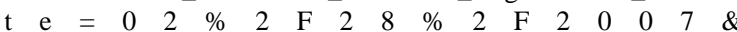
_ s k = $998609997 \&$ vi e w $=$ c \& w c h p $=$ d G L z V t z zSkWz\&md5=70a2de1148e26bf618e402c54144d25e\&ie=>. Doi: 10.1016/j.jviromet.2006.09.022.

JUHASZ, K.; EASTON, A.J. Extensive sequence variation in the attachment $(G)$ protein gene of avian pneumovirus: evidence for two distinct subgroups. Journal of General Virology, v.75 (Pt 11), p.2873-2880, 1994. Disponível em : <http:// vir.sgmjournals.org/cgi/reprint/75/11/2873>. Doi: 10.1099/ 0022-1317-75-11-2873.

KEIGHTLEY, M.C. et al. Real-time NASBA detection of SARSassociated coronavirus and comparison with real-time reverse transcription-PCR. Journal of Medical Virology, v.77, n.4, p.602-
608, 2005. Disponível em: <http://www3.interscience.wiley.com/ journal/112137449>. Doi: 10.1002/jmv.20498.

LOISY, F. et al. Real-time RT-PCR for norovirus screening in shellfish. Journal of Virological Methods, v.123, n.1, p.17, 2005.

MAERTZDORF, J. et al. Real-time reverse transcriptase PCR assay for detection of human metapneumoviruses from all known genetic lineages. Journal of Clinical Microbiology, v.42, p.981-986, 2004. Disponível em : <http://jcm.asm.org/ cgi/reprint/42/3/981>. Doi: 10.1128/JCM.42.3.981-986.2004.

OTSUKI, K. et al. Demonstration of serum-neutralising antibody to turkey rhinotracheitis virus in serum from chicken flocks in Japan. Journal of Veterinary Medical Science, v.58, n.9, p.869-874, 1996.

PABBARAJU, K. et al. Diagnosis and epidemiological studies of human metapneumovirus using real-time PCR. Journal of Clinical Virology, v.40, n.3, p.186-192, 2007. Disponível em: <http://www.journalofclinicalvirology.com/article/ PIIS1386653207002740>. Doi: 10.1016/j.jcv.2007.08.004.

REED, J.I.; MUENCH, H. A simple method for estimating fifth percent endpoints. American Journal Hygiene, v.27, p.493-497, 1938. 